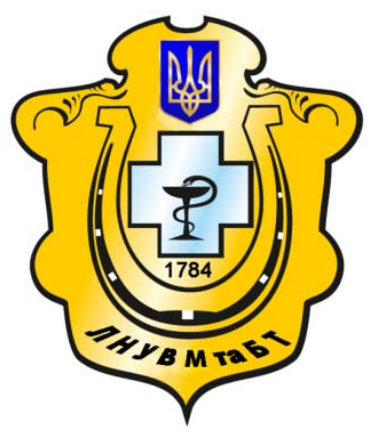

Науковий вісник Львівського національного університету ветеринарної медицини та біотехнологій імені С.3. Гжицького

Scientific Messenger of Lviv National University of Veterinary Medicine and Biotechnologies named after S.Z. Gzhytskyj

doi:10.15421/nvlvet7330

ISSN 2518-7554 print

ISSN 2518-1327 online

$\underline{\text { http://nvlvet.com.ua/ }}$

УДК 619. 614. 34 : 613. 281

\title{
Профілактика міксоматозу кролів
}

\author{
H.I. Кос'янчук \\ ninaiva2@mail.ru \\ Національний університет біоресурсів і природокористування Украӥни, \\ вул. Героїв Оборони, 15, м. Київ, 03041, Україна,
}

Міксоматоз кролів - висококонтагіозне захворювання, збудником якого є епітеліотропний вірус із родини Рохvіridae. Швидкому поширенню хвороби сприяє необізнаність людей щңодо зоогігієнічних, ветеринарно-санітарних та профілактичних заходів при утриманні та вирощуванні поголів'я. Ефективних засобів лікування міксоматозу кролів поки щзо не існує. Тому необхідно дотримуватись загальних зоогігієнічних, ветеринарно-санітарних та профілактичних заходів при утримання тварин, а саме:

- своєчасно проводити планову вакиинацію всього поголів'я кролів. Кроленят вакиинують з місячного віку, у неблагополучних пунктах - 2 28-денного, ревакцинація - через 3 місяці. Щеплення необхідно провести до початку масового льоту комах, найкраще в кінці квітня - на початку травня;

- проводити дезінфекиію, дезінсекиію та дератизацію приміщень;

- знезаражувати гній (біотермічним способом, рідку фракцію - із застосуванням хімічних засобів: формальдегіду, сухого хлорного вапна);

- застосувати репеленти - речовини, щзо відлякують комах (оксамат, бензимін (гексамід) та діетилтолуамід (ДЕТА);

- дотримуватись принципу «Все пусто - все зайнято», щуо дає можливість робити профілактичні перерви, санацію, ремонт, дезінфекиію приміщень;

- діагностику хвороби проводити комплексно з урахуванням епізоотичних даних: сезонність, активність кровосисних комах, випадки захворювання в минулі роки, масовість захворювання.

3 метою профілактики захворювання в Україні застосовують живі, культуральні, ліофілізовані вакиини проти міксоматозу кролів як іноземного, так і украӥнського виробництва. На даний час ТОВ «БІОТЕСТЛАБ» розроблено живу вакцину проти міксоматозу кролів - Лапінум Мікс та Лапінум Гемікс (проти геморагічної хвороби та міксоматозу кролів). Вакцини лінії Лапінум забезпечують швидку імунну відповідь і тривалий захист тварин. Випробування показали наявність антитіл у крові тварин з 4-го дня вакцинації. При виробництві вакцин використовуються итами, які цүілком гомологічні до украӥнських, шуо гарантує ефективність вакизинації.

Ключові слова: міксоматоз, вірус, кролі, вакцина Лапінум МІКС, вакцина Лапінум ГЕМІКС, джерело інфекиії, дезінфекція, профілактика.

\section{Профилактика миксоматоза кролей}

\author{
Н.И. Косьянчук \\ ninaiva2@mail.ru \\ Национальньй университет биоресурсов и природопользования Украиньи, \\ ул. Героев Обороны, 15, г. Киев, 03041, Украина
}

Миксоматоз кролей - высококонтагиозное заболевание, возбудителем которого является епителиотропный вирус из семейства Рохviridae. Быстрому распространению болезни способствует неосведомленность людей относительно зоогигиеническиих, ветеринарно-санитарных и профилактических мероприятий при содержании и выращивании поголовья. Эффективных средств лечения миксоматоза кролей на данный момент не существует. Поэтому необходимо придержи-

Citation:

Kos'yanchuk, N. (2017). The rabbits myxomatosis prophylaxis. Scientific Messenger LNUVMBT named after S.Z. Gzhytskyj, 19(73), 145-148. 
ваться общих зоогигиенических, ветеринарно-санитарных и профилактических мероприятий при содержании жсивотных, а именно:

- своевременно проводить плановую вакцинацию всего поголовья кролей. Крольчат вакцинируют с месячного возраста, а в неблагополучных пунктах - с 28-дневного возраста, ревакцинацчия - через 3 месяцая. Прививку необходимо провести к началу массового лёта насекомых, лучше всего в конце апреля - началу мая месяиа;

- проводить дезинфекцию, дезинсекцию и дератизацию помещзений;

- обеззараживать навоз (биотермическим способом, жидкую фракцию - с применением химических средств: формальдегида, сухой хлорной извести);

- применять репелленть - вещества, которые отпугивают насекомых (оксамат, бензимин (гексамид) и диэтилтолуамид (ДЭТА);

- придерживаться принципа «Все пусто - все занято», что даёт возможность проводить профилактические перерывы, санацию, ремонт, дезинфекцию помещений;

- диагностику болезни проводить комплексно с учётом эпизоотических данных: сезонности, активности кровососуших насекомых, случаев заболевания в предыдущие годы, массовости заболевания.

С ичелью профилактики заболевания в Украине применяют живые, культуральные, лиофилизированные вакцины против миксоматоза кролей, как иностранного, так и украинского производства. В настоящее время ООО «БИОТЕСТЛАБ» разработана живая вакцина против миксоматоза кролей-Лапинум Микс и Лапинум Гемикс (против геморрагической болезни и миксоматоза кролей). Вакичны линии Лапинум обеспечивают быстрый иммунный ответ и длительную зашиту жсивотных. Испытания показали наличие антител в крови животных с 4-го дня вакцинации. При производстве вакцин используются итаммы, которые полностью гомологичны украинским, что гарантирует эффективность вакцинации.

Ключевые слова: миксоматоз, вирус, кроли, вакцина Лапинум МИКС, вакцина Лапинум ГЕМІКС, источник инфекции, дезинфекичя, профилактика.

\title{
The rabbits myxomatosis prophylaxis
}

\author{
N. Kos'yanchuk \\ ninaiva2@mail.ru \\ National University of Life and Environmental Sciences of Ukraine, \\ Heroyiv Oborony Str., 15, Kyiv, 03041, Ukraine
}

Rabbits Myxomatosis - highly contagious disease, which pathogen are epiteliotrophic virus from the family Poxviridae. The rapid spread of the disease contributes people's ignorance in realization of zoohygienic, veterinary and sanitary preventive measures during rabbit farming and breeding. Now, effective treatments against Rabbits Myxomatosis isn't be in existence yet. Therefore, you must implement follow zoohygienic, veterinary and sanitary preventive measures:

- to put on-time routine vaccination of all livestock rabbits. Rabbits vaccinated in month age old, in hazardous areas - in 28-th day age old, revaccination realized in 3 months. It is necessary to do the vaccination before the mass insects fly, the best is during late April - early May;

- to conduct disinfections, disinsections and deratizations measures of animal buildings;

- to conduct measures of manure decontamination (by biotermal way, to the liquid fraction - use follow chemicals: formaldehyde, bleaching powder)

- to apply repellents - substances that repel insects (oksamat, benzymin (hexamid) and diethyltoluamid (DEET);

- to be consistent with the principle «All Empty - All Occupation», which makes it possible to do preventive breaks, sanitary measures, maintenances and disinfection of animals buildings;

- to conduct complex of disease epizootic data diagnostics with regard of: seasonality, the activity of blood-sucking insects, cases in the past, mass disease.

There are use the living cultural lyophilized vaccine against Rabbits Myxomatosis in order to prevent disease in the Ukraine, which made in Ukraine and abroad. Currently, LLC «BIOTESTLAB» developed a live vaccine against Rabbits Myxomatosis Lapinum Mix and Lapinum Hemix (complex against Rabbits Haemorrhagic Disease and Rabbits Myxomatosis). Lapinum lines vaccines provide rapid immune response and long protection against diseases. Tests showed high level of the rabbit blood antibodies from 4-th day of vaccination. In the production of vaccines used same completely homologous Ukrainian virus strains which effective vaccination guarantee.

Key words: myxomatosis virus, rabbits, Lapinum MIX vaccine, Lapinum HEMIX vaccine, source of infection, disinfection, prevention.

\section{Вступ}

Міксоматоз кролів - висококонтагіозне захворювання, збудником якого $є$ епітеліотропний вірус із родини Рoxviridae. Хвороба характеризується високою летальністю з ураженням слизових оболонок i шкіри, утворенням на них вузликів - міксом в ділянці вух, повік, голови, спини, ануса, зовнішніх статевих органів та інших ділянок тіла. Хворіють домашні кролі, незалежно від віку і статі, дикі європейські кролі та зайці. Швидкому поширенню хвороби сприяє необізнаність людей щодо зоогігієнічних, ветеринарно-санітарних та профілактичних заходів при утриманні та вирощуванні кролів.

Метою роботи є розроблення профілактичних заходів при міксоматозі кролів, спрямованих на збереження поголів'я, підвищення продуктивності, зниження економічних збитків від даної хвороби. 


\section{Результати та їх обговорення}

Джерелом інфекції є хворі тварини, а також тварини 3 інкубаційним перебігом хвороби. Кролі, що перехворіли, залишаються вірусоносіями ще тривалий період. Вірус передається при контакті тварин, через їжу, предмети догляду, транспорт. Механічними переносниками інфекції можуть бути собаки, коти, птиця, а також люди, пов'язані з торгівлею тваринами, шкурами та м'ясом кролів (Bondarenko, 2002; Vabyschevych et al., 2011).

Основними переносниками збудника є кровосисні комахи - комарі і москіти, а також ектопаразити кліщі, блохи, воші, в хоботку яких вірус зберігає свою активність. Так, комарі можуть передавати вірус до 30-36 днів після потрапляння його в організм комахи. У слинних залозах москітів вірус міксоми зберігається до 7 міс. Кролячі блохи є носіями вірусу протягом 3-4 міс. при їх голодуванні.

Вченими встановлено, що збудник міксоматозу не здатний розмножуватись в організмі членистоногих. Імовірно, що комарі і кролячі блохи є лише резервуаром збудника міксоми в природі і механічними переносниками вірусу зі шкірних міксомних уражень хворих кролів.

Епізоотії міксоматозу виникають в теплий період року. При температурі $8-10{ }^{\circ} \mathrm{C}$ вірус зберігає вірулентність протягом 3 міс., у трупах кролів - до 7 днів, висушених шкурках при $15-20{ }^{\circ} \mathrm{C}$ - до 10 міс., в замороженому стані - понад 2 роки.

Пік захворювання припадає на кінець літа і осінь, що пов'язано 3 активністю комарів i формуванням сприятливих умов для їх масового розмноження. Міграції кровосисних комах сприяють поширенню інфекції на відстань до 250 кілометрів від первинного вогнища.

Інкубаційний період триває від 2 до 20 днів. Хвороба може перебігати у двох формах - класичній (набряковій) і нодулярній (вузликовій). Класична форма захворювання більш небезпечна, смертність при ній досягає 100\%, нодулярна - супроводжується доброякісним перебігом, але смертність теж висока - 70 90\% (Sobko and Priskoka, 2006).

Перебіг захворювання може бути блискавичним, гострим, підгострим та хронічним. Блискавична форма хвороби призводить до раптової загибелі кроликів - через 2-3 дні після зараження. Гостра форма (найбільш поширена) характеризується гнійним запаленням повік, виникненням на губах та носі набрякових пухлин, які надають голові тварини потворного вигляду - «левова голова». Набряки з'являються також на вухах, лапах, спині, ділянках статевих органів i анального отвору. Розвивається запалення слизових оболонок носоглотки, що викликає утруднене дихання та ковтання. Кролі погано їдять, стають кволими, швидко худнуть і через 7-10 днів після початку захворювання гинуть. Хронічна форма хвороби може закінчуватись видужанням тварин, в результаті чого кролі набувають активного імунітету. Кроленята, які народилися від матерів-реконвалесцентів, залишаються стійкими до міксоматозу до п'яти тижневого віку.
У разі виникнення хвороби усіх кролів поділяють на дві групи: хворі та 3 підозрою на захворювання (клінічно здорові). Хворих кролів відповідно до «Правил передзабійного ветеринарного огляду тварин i ветеринарно-санітарної експертизи м'яса та м'ясних продуктів» забивають і знищують разом із шкурками.

Клінічно здорових кролів імунізують. Тварини, що на час вакцинації були носіями вірусу, можуть захворіти і підлягають забою. Хворих кроликів забивають і спалюють разом зі шкуркою. Кролів, які не мають ознак захворювання, але перебували разом із хворими, забивають, м'ясо їх проварюють 2-3 години або піддають термічній обробці та використовують в їжу, а шкурки і внутрішні органи спалюють. Гній, підстилку і залишки кормів від хворих кролів та тварин, що контактували з ними спалюють. Приміщення кролятника, клітки та інвентар чистять і дезінфікують одним iз дезінфікуючих розчинів: 3\% розчином каустичної соди або формаліну, 1\% розчином формальдегіду, 2\% розчином хлораміну або дезмолу, $3 \%$ гарячим $\left(70{ }^{\circ} \mathrm{C}\right)$ розчином їдкого натру, або аерозольно формаліном (на $1 \mathrm{~m}^{3}$ приміщення витрачають 15-20 $\mathrm{cm}^{3}$ препарату), $0,5 \%$ розчином віроциду або віросану у вигляді розчину, спрію, туману, піни.

За 2 дні до посадки молодняку та при ввезенні нового стада проводити дезінфекцію кролятника віросаном (з розрахунку 5 мл на 1 л води зрошенням, не змиваючи) або іншими дезінфектантами. Для профілактичної, поточної та заключної дезінфекції приміщень, обладнання, транспорту доцільно застосовувати біодез Р.

Карантин знімають з неблагополучного пункту через 15 днів після останнього випадку захворювання та проведення ветеринарно-санітарних заходів. У неблагополучний пункт заборонено ввозити кролів впродовж 2 місяців після зняття карантину, у загрозливу зону - впродовж 1 місяця.

Ефективних засобів лікування міксоматозу кролів поки що не існує. Та й лікувати хворих на міксоматоз тварин недоцільно, адже це збільшує ризик поширення вірусу. Тому, насамперед, необхідно дотримуватись загальних ветеринарно-санітарних заходів при утримання тварин, а саме:

- своєчасно проводити планову вакцинацію всього поголів'я кролів. Кроленят вакцинують 3 місячного віку, у неблагополучних пунктах - $з$ 28-денного. Ревакцинацію кролів проводять через 3 місяці. Щеплення необхідно провести до початку масового льоту комах, найкраще в кінці квітня - початку травня;

- проводити дезінфекцію, дезінсекцію та дератизацію приміщень;

- знезаражувати гній (біотермічним способом, рідку фракцію - застосуванням хімічних засобів: формальдегіду, сухого хлорного вапна);

- застосувати репеленти - речовини, що відлякують комах (оксамат, бензимін (гексамід) та діетилтолуамід (ДЕТА);

- дотримуватись принципу «Все пусто - все зайнято», що дає можливість робити профілактичні перерви, санацію, ремонт, дезінфекцію приміщень;

- діагностику хвороби проводити комплексно 3 урахуванням епізоотичних даних: сезонність, актив- 
ність кровосисних комах, випадки захворювання в минулі роки, масовість захворювання;

- урахування клінічних ознак. На початку хвороби спостерігають припухання та почервоніння повік, набряки шкіри, підшкірної клітковини. Згодом за декілька днів утворюються щільні вузлики, розміром від просяного зерна до квасолини, набряки підшкірної клітковини в ділянці голови більшають і розвивається ознака, так звана «левова голова» - шкіра збирається в складки, потовщується. Хвороба ускладнюється гнійними кон'юнктивітом, ринітом. Окрім голови, набряки утворюються в ділянці статевих органів, анусу;

- урахування патологоанатомічних ознак, таких як драглисті набряки і вузли в ділянці голови, шиї спини, повік.

До лабораторії надсилають трупи нещодавно загиблих кролів або шматки шкіри із ділянками ураження. В лабораторії досліджують матеріал гістологічним методом та постановкою біопроби на невакцинованих кролях, рекомендована також реакція дифузної преципітації.

3 метою профілактики захворювання в Україні застосовують живі, культуральні, ліофілізовані вакцини від міксоматозу кролів як іноземного, так і українського виробництва. Вітчизняні препарати виготовляють Сумська та Херсонська державні біофабрики, а також ТОВ «БІОТЕСТЛАБ». На даний час ТОВ «БІОТЕСТЛАБ» розроблено живу вакцину проти міксоматозу кролів - Лапінум Мікс та Лапінум Гемікс (геморагічної хвороби та міксоматозу кролів). Вакцини лінії Лапінум забезпечують швидку імунну відповідь і більш тривалий захист тварин. Випробування показали наявність антитіл 3 4-го дня вакцинації. Вакцини Лапінум долають залишкові колостральні антитіла кроленяти, тому дозволяється рання вакцинація - 3 28-го дня ( раніше цього терміну вакцинація не має сенсу - кроленя захищене материнськими антитілами). При виробництві вакцин використовуються штами, які цілком гомологічні до українських, що гарантує ефективність вакцинації. Підшкірне (за лопаткою) введення вакцин ін'єкцією в місце зі слабко розвиненим кровоносним руслом подовжує термін захисту тварин. Виробник зазначає, що вакцинація за 7 днів перед окролом небажана через ризик отримання травми та стресу, що може призвести до аборту. Вакцинують лише клінічно здорових кролів, ревакцинація кожні 8 місяців.

Крім того, на території України зареєстровані іноземні асоційовані вакцини виробництва Росії, Чехії та Словаччини проти міксоматозу та геморагічної хвороби кролів, але практика показує, що при застосуванні таких вакцин часто розвивається нестійкий імунітет. В таких випадках нерідко трапляється «прорив імунітету», частіше стосовно міксоматозу.

\section{Висновки}

1. Лікування міксоматозу кролів недоцільне - це збільшує ризик поширення вірусу, тому важливе значення мають профілактичні заходи, що забезпечують благополуччя тварин.

2. Важливо вчасно проводити вакцинацію і ревакцинацію всього поголів’я.

\section{Бібліографічні посилання}

Bondarenko, S.P. (2002). Bolezni pushnich zverey [Diseases of fur-bearing animals]. Donetsk: Publ.h. «Stalker», 102-104 (in Russian).

Vabyschevych, F.S., Vabyshevych, F.F., Matlak, D.A., Demidenko, T.M., Pechura, O. (2011). Miksomatoz ta gemoragichna hvoroba kroliv. Vakcini - vashvibir. [Myxomatosis and rabbit haemorrhagic disease.Vaccines - your choice] Modern veterinary medicine. 1, 11-16 (in Ukrainian).

Sobko, Yu.A., Priskoka, V.A. (2006). Miksomatoz kroley [Mixomatosis of rabbits]. Modern veterinary medicine. 7,33 .

Pravila perezbiynogo veterinarnogo oglyadu tvarun i veterinarno-sanitarnoi ekspertuzu myasa ta myasoproduktiv (2002). [Terms ante mortem inspection of animals and veterinary-sanitary examination of meat and meat products] from 21 June 2002 year by №524/6812 (in Ukrainian).

Стаття надійшла до редакиії 10.03.2017 